Kikkawa, Y, Kamimura, K., Hamaijma, T., Sekiguchi, T., Kawai, T., Takenaka, M. and Tada, T. (1973). Thymic alymphoplasia with hyper-IgE-globulinemia. Pediatrics, 51, 690.

Lawlor, G. J., Ammann, A. J., Wright, W. C., La Franchi, S. H., Bilstrom, D., and Stiehm, E. R. (1974). Syndrome of cellular immunodeficiency with immunoglobulins. Fournal of Pediatrics, 84, 183.

Nezelof, C., Jammet, M. L., Lortholary, P., Labrune, B., and Lamy, M. (1964). L'hypoplasie hereditaire du thymus. Archives Francaises de Pédiatrie, 21, 897.

Rubinstein, A., Speck, B., and Jeannet, M. (1971). Successful bone-marrow transplantation in a lymphopenic immunologic deficiency syndrome. New England fournal of Medicine 285, 1399.

Zembala, M., and Asherson, G. L. (1973). Depression of the T cell phenomenon of contact sensitivity by $T$ cells from unresponsive mice. Nature, 244, 227.

A. D. B. Webster,* G. Slavin, M. K. Strelling, and G. L. ASHERSON

Clinical Research Centre, Northwick Park Hospital, Harrow, Middlesex; and Department of Paediatrics, Plymouth General Hospital, Devon.

^Correspondence to Dr. A. D. B. Webster, Northwick Park Hospital, C. R. C. Harrow, Middx. HAl 3UJ.

\section{Trial of artificial diet in treatment of cystic fibrosis of pancreas}

The major clinical features of cystic fibrosis (CF) of the pancreas include, with rare exceptions, malabsorption, malnutrition, and growth failure. Standard treatment of this disease includes the use of a high calorie, high protein diet and pancreatic enzyme supplements to improve intestinal absorption. Even with such treatment nutrition and growth may be impaired, and undernutrition may further predispose to respiratory infections.
Darby and Seakins (1971) described the use of a dietary amino acid supplement in treatment of CF but noted no benefit to their patients. More recently, Allen, Mason, and Moss (1973) have reported encouraging results from the use of an artificial diet in the treatment of CF, with evidence of improvement in growth and clinical status.

We report our experience with the use of an artificial diet in a group of patients with CF.

\section{Patients and methods}

Twelve patients with $\mathrm{CF}$, whose ages ranged from 4 months to 12 years and who had all been previously treated with normal diet plus pancreatic enzyme supplements, were started on an artificial diet similar to that described by Allen et al. (1973). This consisted of Albumaid (a beef protein hydrolysate) and Caloreen (a glucose polymer), prescribed in sufficient quantities to provide $100 \%$ of the patient's protein and calorie requirements. It was given in water, flavoured to taste with tomato or fruit juice, or in the case of infants dissolved in sufficient water to provide the total daily fluid intake. Additional eating was discouraged, but additional fluids were permitted. All patients were given daily $10 \mathrm{ml}$ medium chain triglyceride oil, Ketovite tablets, and liquid, and a standard mineral supplement. Pancreatic enzymes were only given when any normal food was taken. Normal treatment, including physiotherapy and antibiotics in the presence of chest infection, was continued throughout the period of the trial. The trial period was for a full year in each case. If the patients found difficulty in keeping to the diet, the follow-up and observations described below were continued for a full year and advice and encouragement to continue with the diet were offered at each visit.

At the beginning of the trial patients were examined clinically and classified into grades 1 or 2 using the criteria similar to those recently described by Mearns (1972) for assessing respiratory status. Patients without

TABL\&

Patients who took the diet alone

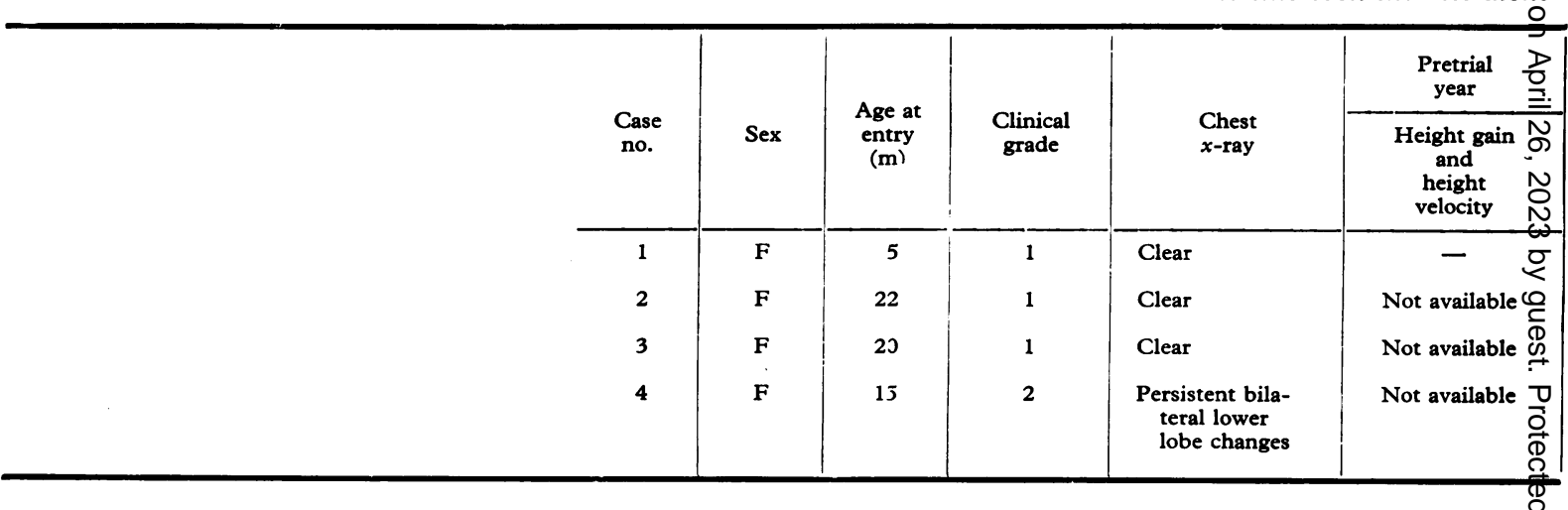


added sounds on auscultation who had no or minimal cough, and who had no pathogens cultured from pharyngeal swabs were considered to be in grade 1 . Patients were seen at 6-weekly intervals; weight was measured at each visit, and height or length was measured every 3 months. After a full year, weight and height velocities were calculated and compared to the centile standards described by Tanner, Whitehouse, and Takaishi (1966). Chest signs and stool frequency were recorded and sputum cultured at each visit. Chest $x$-rays were taken at the beginning of the trial and again at the end of the year.

\section{Results}

The clinical features of the 12 patients are outlined in Tables I and II. The 4 youngest patients (Cases 1-4) comprise a younger group who tolerated the diet well, and at the end of the year all were still taking the full amount of diet with little or no additional food. The first 3 patients all showed accelerated growth with catch up in weight, and to a lesser extent in height.

The parents of all these patients were impressed by their improvement in general well being and activity, and by the improvement in stool frequency and consistency. The fourth patient showed no improvement in her growth rate. She had presented initially with meconium ileus, had already had one severe episode of respiratory infection, and had persisting signs in her chest clinically and radiologically. During the year she had 2 further episodes of respiratory infection.

The 8 older children found the diet monotonous and often unpleasant, and despite good parental co-operation it was difficult to persuade them to continue with it. The first 3 of these were classified as grade 1. The first (Case 5) refused to take any of the diet after only 2 weeks and was subsequently given a normal diet plus pancreatic enzyme supplements. At the beginning of the year his height and weight were on the 50th centile but over the year his growth velocity was only on the 25 th centile.

The remaining 2 children who were classified as grade 1 persevered with the diet alone for almost 3 months. Thereafter they took increasing amounts of normal food (plus pancreatic enzyme supplements) and by the end of the year were taking almost a normal diet with only an occasional supplement of Albumaid. Both children had two to three bulky stools daily during the period preceding the trial, and both reported less frequent and more formed stools while on the Albumaid diet alone. With increasing intake of food the stool frequency and consistency reverted to the previous pattern. Both these girls showed a noticeable weight gain during the period on the diet alone. Over such a short period, however, no height increase was noted. Weight increase ceased once they began to eat additional foods. Over the year as a whole no acceleration in growth was noted.

The remaining 5 older children were all clinically grade 2. All adhered reasonably well to the diet for 2 or 3 months, and then began to eat increasing amounts of normal food, usually cutting down on the amount of Albumaid. None showed any increase in weight or height during the year as a whole, or even during the time they were taking the diet alone.

During the year there were ten episodes of severe respiratory infection in this group, with 2 deaths. In both fatal cases the organism isolated was Pseudomonas pyocyanea. No patient showed any improvement in chest $x$-ray changes over the year.

I

for the whole year-clinical details

\begin{tabular}{|c|c|c|c|}
\hline $\begin{array}{l}\text { Pretrial } \\
\text { year }\end{array}$ & $\begin{array}{l}\text { Trial } \\
\text { year }\end{array}$ & $\begin{array}{l}\text { Trial } \\
\text { year }\end{array}$ & \\
\hline $\begin{array}{l}\text { Weight gain } \\
\text { and } \\
\text { weight } \\
\text { velocity }\end{array}$ & $\begin{array}{c}\text { Height gain } \\
\text { and } \\
\text { height } \\
\text { velocity }\end{array}$ & $\begin{array}{c}\text { Weight gain } \\
\text { and } \\
\text { weight } \\
\text { velocity }\end{array}$ & Progress \\
\hline $\begin{array}{l}1 \mathrm{~kg} \text { in } 1 \mathrm{st} 5 \mathrm{~m} \\
\text { of life } \\
1.8 \mathrm{~kg} / \mathrm{yr} \\
<25 \mathrm{th} \text { centile } \\
1.5 \mathrm{~kg} / \mathrm{yr} \\
10 \text { th centile } \\
3.4 \mathrm{~kg} \text { in } 1 \mathrm{st} \mathrm{yr} \\
10 \text { th centile }\end{array}$ & $\begin{array}{l}20 \mathrm{~cm} / \mathrm{yr} \\
>90 \text { th centile } \\
11 \mathrm{~cm} / \mathrm{yr} \\
>75 \text { th centile } \\
11 \mathrm{~cm} / \mathrm{yr} \\
75 \text { th centile } \\
7 \mathrm{~cm} / \mathrm{yr} \\
<10 \text { th centile }\end{array}$ & $\begin{array}{l}5 \cdot 8 \mathrm{~kg} / \mathrm{yr} \\
75 \text { th centile } \\
4 \mathrm{~kg} / \mathrm{yr} \\
>90 \text { th centile } \\
3 \mathrm{~kg} / \mathrm{yr} \\
>75 \mathrm{th} \text { centile } \\
1 \cdot 5 \mathrm{~kg} / \mathrm{yr} \\
10 \text { th centile }\end{array}$ & $\begin{array}{l}\text { Stool frequency } \\
\text { decreased } \\
\text { Stool frequency } \\
\text { decreased } \\
\text { Stool frequency } \\
\text { decreased } \\
\text { Stool frequency } \\
\text { decreased; } \\
2 \text { chest infections }\end{array}$ \\
\hline
\end{tabular}


Patients who took additio

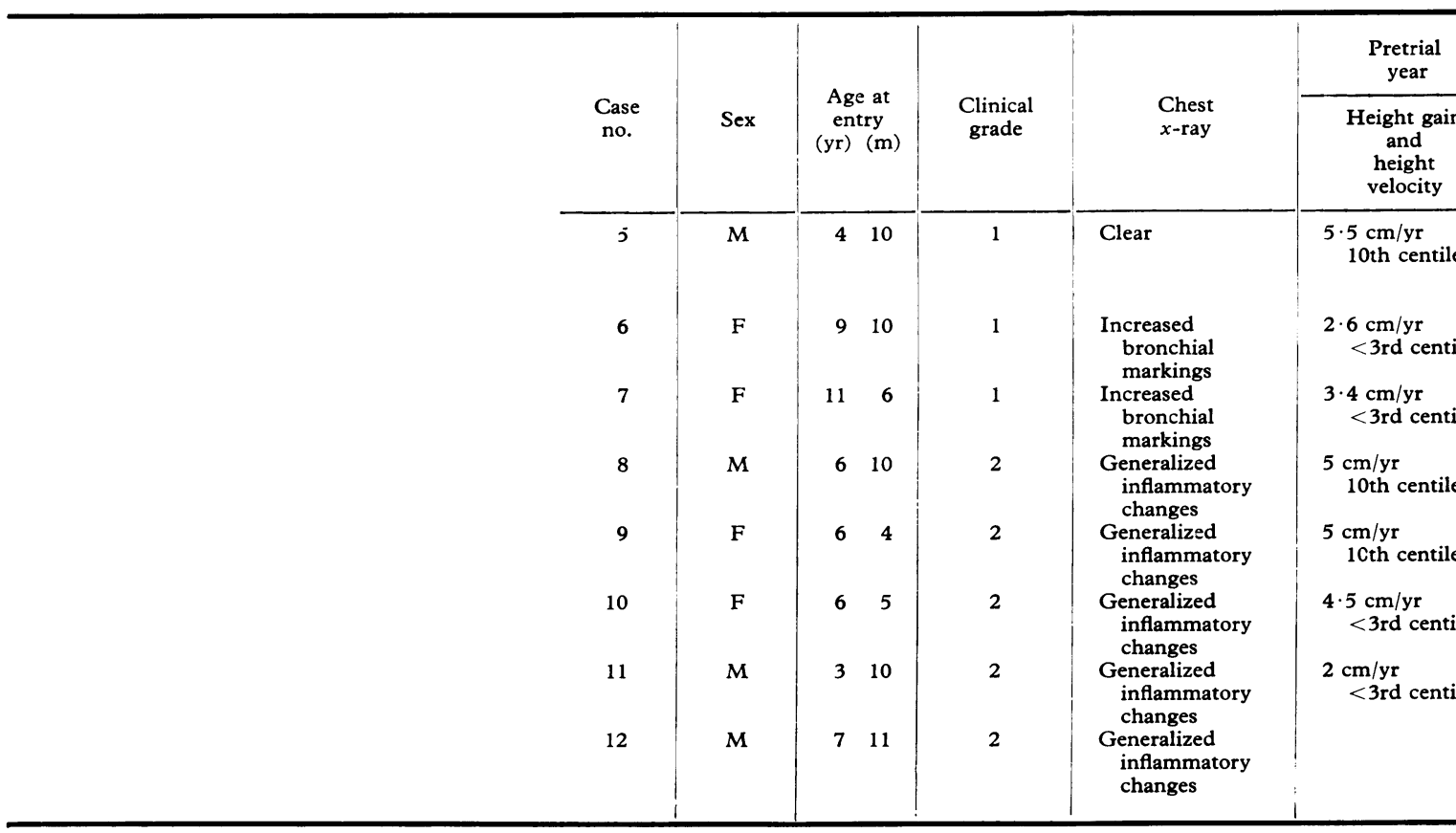

\section{Discussion}

To justify imposing a strict and unpalatable diet on children with CF, definite benefits in terms of improved well being and prognosis should be expected. The patients who showed most convincing evidence of improved growth and well being were those less severely affected (Cases 1-3). In addition, these children all tolerated the diet well and took only minimal, if any, additional food.

Two older children (Cases 6 and 7) were also in the less severely affected group. Initially they showed increased weight gain and improved stool frequency, but this improvement was not maintained. Our impression was that this was related to the reintroduction of substantial amounts of normal food into the diet.

The patients in our series with more advanced disease as judged by clinical radiological criteria showed no apparent improvement in growth or general health while on the diet and their respiratory infections were no less severe or frequent. In such patients the adverse effects of tissue hypoxia and chronic bacterial infections may prevent any benefit accruing from improved absorption of nutrients.
The only patients therefore who showed definite benefit were those children who fulfilled two criteria-those who were less severely affected by the disease, and who tolerated the diet well, taking little or no additional food.

Over a period of a year we cannot judge whether improved nutritional status will be paralleled by fewer respiratory complications and improved long-term prognosis. We have been sufficiently encouraged by the improvement in 3 of our younger patients to continue with the diet, though it may become harder to exclude additional foods as they grow older, and eating becomes governed by social habit as well as hunger.

\section{Summary}

Twelve patients with cystic fibrosis were started on an artificial diet of Albumaid and Caloreen, together with a supplement of medium chain triglyceride oil, vitamins, and minerals. Growth velocity and general health were assessed over a period of a full year for each child. Patients who were only mildly affected by the disease showed improvement in stool frequency and growth rate 
II

food-clinical details

\begin{tabular}{|c|c|c|c|}
\hline $\begin{array}{l}\text { Pretrial } \\
\text { year }\end{array}$ & $\begin{array}{l}\text { Trial } \\
\text { year }\end{array}$ & $\begin{array}{l}\text { Trial } \\
\text { year }\end{array}$ & \\
\hline $\begin{array}{l}\text { Weight gain } \\
\text { and } \\
\text { weight } \\
\text { velocity }\end{array}$ & $\begin{array}{l}\text { Height gain } \\
\text { and } \\
\text { height } \\
\text { velocity }\end{array}$ & $\begin{array}{l}\text { Weight gain } \\
\text { and } \\
\text { weight } \\
\text { velocity }\end{array}$ & Progress \\
\hline $\begin{array}{l}1 \cdot 6 \mathrm{~kg} / \mathrm{yr} \\
<25 \text { th centile }\end{array}$ & $\begin{array}{l}5 \mathrm{~cm} / \mathrm{yr} \\
\quad<10 \text { th centile }\end{array}$ & $\begin{array}{l}1 \mathrm{~kg} / \mathrm{yr} \\
25 \mathrm{th} \text { centile }\end{array}$ & $\begin{array}{l}\text { Refused diet after } 2 \\
\text { weeks; normal food } \\
\text { plus enzyme } \\
\text { thereafter }\end{array}$ \\
\hline $\begin{array}{l}0.7 \mathrm{~kg} / \mathrm{yr} \\
<3 \text { rd centile }\end{array}$ & $\begin{array}{l}5 \mathrm{~cm} / \mathrm{yr} \\
<25 \text { th centile }\end{array}$ & $\begin{array}{l}1 \cdot 8 \mathrm{~kg} / \mathrm{yr} \\
>10 \text { th centile }\end{array}$ & $\begin{array}{l}1.5 \mathrm{~kg} \text { in first } 2 \mathrm{~m} \text { on } \\
\text { diet alone }\end{array}$ \\
\hline $\begin{array}{l}1 \mathrm{~kg} / \mathrm{yr} \\
<3 \mathrm{rd} \text { centile }\end{array}$ & $\begin{array}{l}4.5 \mathrm{~cm} / \mathrm{yr} \\
<10 \text { th centile }\end{array}$ & $\begin{array}{l}1 \cdot 4 \mathrm{~kg} / \mathrm{yr} \\
\quad<3 \text { rd centile }\end{array}$ & $\begin{array}{l}1.65 \mathrm{~kg} \text { in first } 4 \mathrm{~m} \text { diet } \\
\text { alone }\end{array}$ \\
\hline $\begin{array}{l}0.85 \mathrm{~kg} / \mathrm{yr} \\
3 \mathrm{rd} \text { centile }\end{array}$ & $\begin{array}{l}3.6 \mathrm{~cm} / \mathrm{yr} \\
<10 \text { th centile }\end{array}$ & $\begin{array}{l}0.6 \mathrm{~kg} / \mathrm{yr} \\
<3 \mathrm{rd} \text { centile }\end{array}$ & No change \\
\hline $\begin{array}{l}1 \cdot 5 \mathrm{~kg} / \mathrm{yr} \\
\text { Just }>10 \text { th } \\
\text { centile }\end{array}$ & $\begin{array}{l}4 \cdot 5 \mathrm{~cm} / \mathrm{yr} \\
<10 \text { th centile }\end{array}$ & $\begin{array}{l}1 \cdot 2 \mathrm{~kg} / \mathrm{yr} \\
<10 \text { th centile }\end{array}$ & 2 chest infections \\
\hline $\begin{array}{l}1 \cdot 8 \mathrm{~kg} / \mathrm{yr} \\
>25 \text { th centile }\end{array}$ & $\begin{array}{l}4 \mathrm{~cm} / \mathrm{yr} \\
<3 \mathrm{rd} \text { centile }\end{array}$ & $\begin{array}{l}1 \mathrm{~kg} / \mathrm{yr} \\
<3 \mathrm{rd} \text { centile }\end{array}$ & 3 chest infections \\
\hline $0.5 \mathrm{~kg} / \mathrm{yr}$ & $\begin{array}{l}1 \mathrm{~cm} / \mathrm{yr} \\
<3 \mathrm{rd} \text { centile } \\
\text { No gain }\end{array}$ & $\begin{array}{l}\text { No gain } \\
\text { Lost } 0.5 \mathrm{~kg}\end{array}$ & $\begin{array}{l}2 \text { chest infections; } \\
\text { died after } 8 \mathrm{~m} \\
3 \text { chest infections; } \\
\text { died after } 2 \mathrm{~m}\end{array}$ \\
\hline
\end{tabular}

when the diet represented the major part of their nutritional intake. Patients who were severely affected showed no improvement in growth, general clinical status, or frequency of respiratory infections.

We are grateful to the consultant paediatricians of this hospital who have allowed us to study patients under their care, and particularly to Dr. W. Morton Fyfe for advice and criticism.

\section{REFERENCES}

Allen, J. D., Mason, A., and Moss, A. D. (1973). Nutritional supplementation in treatment of cystic fibrosis of the pancreas. American Fournal of Diseases of Children, 126, 22.
Darby, C., and Seakins, J. W. T. (1971). Trial of amino acid supplements in cystic fibrosis of the pancreas. Archives of Disease in Childhood, 46, 866.

Mearns, M. B. (1972). Treatment and prevention of pulmonary complications of cystic fibrosis in infancy and early childhood. Archives of Disease in Childhood, 47, 5.

Tanner, J. M., Whitehouse, R. H., and Takaishi, M. (1966) Standards from birth to maturity for height, weight, height velocity, and weight velocity: British children, 1965. Archives of Disease in Childhood, 41, 613.

R. P. C. Barclay and Rosemary S. Shannon Division of Medical Paediatrics, Stobhill General Hospital, Glasgow G21 3UW. 